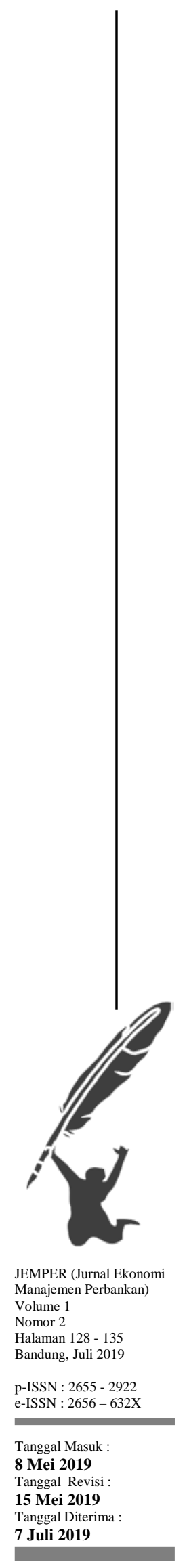

JEMPER(Jurnal Ekonomi Manajemen Perbankan)

http://jurnal.usbypkp.ac.id/index.php/jemper

\title{
PENGARUH HARGA MINYAK DUNIA, SUKU BUNGA, INFLASI DAN NILAI TUKAR TERHADAP HARGA SAHAM SEKTOR PERTAMBANGAN PADA INDEKS LQ45 PERIODE 2011-2018
}

\author{
Fitrah Auliana ${ }^{1}$ \\ Universitas Sangga Buana YPKP Bandung \\ fitraahaulianaa@gmail.com \\ Tahmat $^{2}$ \\ Universitas Sangga Buana YPKP Bandung \\ tahmatdj@gmail.com
}

\begin{abstract}
The purpose of this study is to find out and analyze the influence of partial and simultaneously of external factors of the company specifically crude oil price, interest rate, inflation and exchange rate towards mining stock price. Object of this study are mining companies that listed in Indonesian Stock Exchange and entered in LQ45 indices period of 2011- 2018. Method of analysis in this research is panel data regression analysis. With purposive sampling method, 13 companies obtained that will be the object of research.Based on research results, crude oil price, interest rate, inflation and exchange rate have simultaneously effect towards mining stock prices. But in partially, just crude oil price and interest rate have effect towards mining stock prices, while inflation and exchage rate haven't partially effect towards mining stock price in LQ45 indices period of 2011-2018.
\end{abstract}

Keywords: Crude Oil Price, Interest Rate, Inflation, Exchange Rate

\begin{abstract}
Abstrak
Tujuan dari penelitian ini adalah untuk mengetahui dan menganalisis pengaruh faktor eksternal perusahaan yaitu harga minyak dunia, suku bunga, inflasi dan nilai tukar terhadap pergerakan harga saham baik secara simultan dan secara parsial. Penelitian ini mengambil objek pada perusahaan pertambangan yang terdaftar di Bursa Efek Indonesia (BEI) dan masuk ke dalam list Indeks LQ45 untuk periode 2011 sampai 2018. Metode analisis yang digunakan yaitu metode analisis regresi data panel. Dengan metode purposive sampling, diperoleh sebanyak 13 perusahaan yang akan dijadikan objek penelitian.Berdasarkan hasil penelitian, diketahui bahwa secara simultan, Harga Minyak Dunia, Suku Bunga, Inflasi dan Nilai Tukar berpengaruh terhadap pergerakan harga saham. Namun secara parsial, hanya Harga Minyak Dunia dan Suku Bunga yang berpengaruh terhadap pergerakan harga saham, sedangkan Inflasi dan Nilai Tukar tidak berpengaruh terhadap pergerakan harga saham perusahaan sektor pertambangan pada Indeks LQ45 untuk periode tahun 2011-2018.
\end{abstract}

Kata kunci : Harga Minyak Dunia, Suku Bunga, Inflasi, Nilai Tukar 


\section{PENDAHULUAN}

Pasar modal merupakan alternatif pendanaan bagi perusahaan yang ingin terus berkembang atau memperluas usaha. Salah satu instrumen pasar modal yang tengah populer ialah saham, karena dengan memiliki saham maka pihak tersebut akan mendapatkan hak atas keuntungan dari saham yang dimiliki. Dari beberapa sektor saham yang dapat diperjualbelikan, salah satu yang saat ini sering menunjukkan aktivitas positif ialah sektor pertambangan. Karena potensi keuntungan yang didapat dari saham bisa dikatakan tinggi, begitupun tingkat risikonya. Pergerakan harga saham cenderung cepat dan fluktuatif maka saham sering disebut sebagai instrumen yang memiliki tingkat risiko tinggi. Untuk itu penting bagi para investor maupun trader untuk memahami perkembangan tren harga saham ketika akan mengambil keputusan, salah satunya dengan mengetahui indeks harga saham. Indeks LQ45 menjadi indeks yang diminati banyak investor dan trader, karena terdiri dari 45 emiten yang memiliki kemampuan perusahaan yang baik, yaitu memenuhi kriteria tertentu seperti memiliki kapitalisasi pasar tertinggi, nilai transaksi tertinggi, memiliki kondisi keuangan dan prospek pertumbuhan yang tinggi.

Grafik dibawah menunjukkan perkembangan harga minyak dunia, suku bunga, inflasi, nilai tukar dan harga saham indeks LQ45.

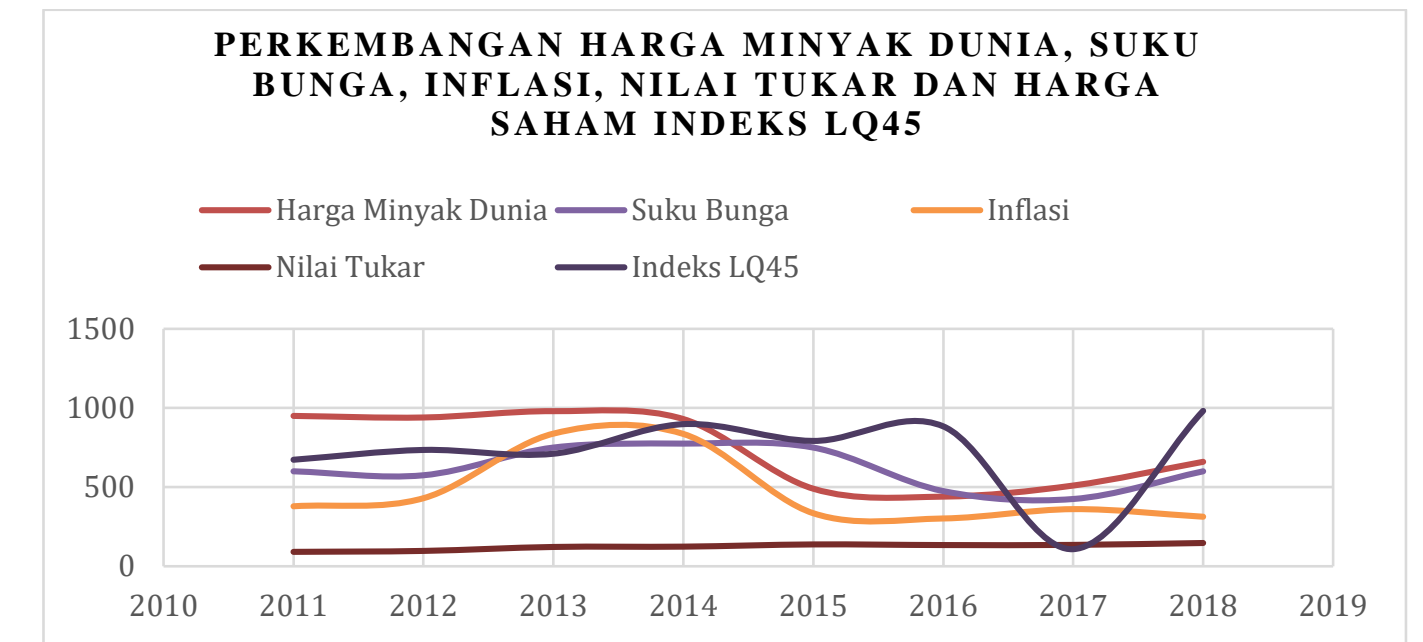

Grafik 1 Perkembangan Harga Minyak Dunia, Suku Bunga, Inflasi, Nilai Tukar Dan Harga Saham Indeks LQ45

Dapat dilihat dalam 8 tahun, pergerakan harga minyak dunia fluktuatif, pada tahun 2014 pergerakan mulai turun tidak berbanding lurus dengan harga saham yang bergerak naik.Begitu pula pergerakan suku bunga, ketika suku bunga naik investor akan lebih tertarik untuk menarik investasinya dari bentuk saham ke dalam bentuk tabungan dan deposito, maka harga saham akan turun akibat permintaan yang menurun. Namun pada tahun 2014 ketika suku bunga turun, pergerakan harga saham ikut turun padahal sebenarnya ketika suku bunga turun seharusnya harga saham naik karena para investor akan mengalihkan investasinya kembali pada saham yang artinya permintaan akan saham meningkat. Pada tahun 2014 ketika inflasi turun, harga saham pun ikut turun, padahal sebenarnya ketika inflasi turun harga saham akan naik karena turunnya harga barang-barang yang akan berpengaruh terhadap keuntungan perusahaan. Dari tahun 2011 hingga 2018 harga saham cenderung mengalami kenaikan tidak berbanding lurus dengan nilai tukar rupiah, karena ketika nilai tukar rupiah turun seharusnya harga saham ikut turun karena terdepresiasinya nilai rupiah.

Meskipun indeks LQ45 memiliki emiten dengan kualitas perusahaan yang baik tetap saja investor dan trader harus memperhatikan sentimen pasar agar kegiatan yang berkaitan dengan saham dapat berjalan dengan baik. Selain memperhatikan indeks, para investor dan 
trader juga perlu memperhatikan perkembangan ekonomi baik global maupun dalam negeri. Salah satu sektor saham yang saat ini memiliki kontribusi cukup baik bagi kinerja Indeks LQ45 ialah pertambangan.

Dilansir dari CNBC Indonesia (2018) dengan judul Saham-saham Tambang Penahan Laju Koreksi LQ45. Saham-saham dari sektor pertambangan tercatat paling banyak yang menguat di jajaran LQ45 selama sembilan bulan pertama 2018. Ini sejalan dengan kenaikan harga-harga komoditas pertambangan di pasaran dunia. Pergerakan harga saham sektor pertambangan tidak serta merta hanya dipengaruhi oleh harga komoditas tambang saja . Berdasarkan penelitian yang dilakukan Murcia dan Tamayo (2015), menyatakan bahwa tingkat inflasi memiliki hubungan positif signifikan terhadap indeks harga saham sektor mining and oil. Penelitian yang dilakukan oleh Rohmanda (2014) menyatakan nilai tukar (kurs) Rupiah terhadap Dollar Amerika Serikat berpengaruh signifikan terhadap seluruh indeks harga saham sektoral di Bursa Efek Indonesia. Investor akan melepaskan saham di pasar modal akibat depresiasi mata uang.

\section{LITERATUR}

\section{Harga Minyak Dunia}

Harga minyak mentah dunia diukur dari harga spot pasar minyak dunia, pada umumnya yang digunakan menjadi standar adalah Brent (Brent Crude) merupakan nilai standarisasi minyak yang sumbernya berasal dari laut utara (eropa) sedang nama Brent berasal dari lahan tambang di laut utara, yang dibuka pada tahun 1970. Harga minyak Brent menjadi dasar pembentukan harga sejak tahun 1971. Namun, dalam perkembangannya, karena produksi dari Brent terus mengalami penurunan maka sejak 2007 berkembang standarisasi harga baru yaitu WTI (idx.co.id).

\section{Suku Bunga}

Tingkat suku bunga adalah harga dari penggunaan dana investasi (loanable funds). Tingkat suku bunga merupakan salah satu indikator dalam menentukan apakah seseorang akan melakukan investasi atau menabung (Boediono, 2014:76). Suku bunga yang menjadi acuan di Indonesia ialah BI Rate namun sejak 2016 suku bunga acuan merubah menjadi BI Seven Days Repo Rate.

\section{Inflasi}

Inflasi adalah kecenderungan meningkatnya harga barang dan jasa secara umum dan terus menerus (M. Natsir, 2014 : 253).

\section{Nilai Tukar}

Nilai Tukar (kurs) merupakan harga suatu mata uang relatif terhadap mata uang negara lain. Kurs memainkan peranan penting dalam keputusan-keputusan pembelanjaan, karena kurs memungkinkan kita menerjemahkan harga-harga dari berbagai negara ke dalam satu bahas yang sama (Mahyus Ekananda, 2014 : 168).

\section{Hipotesis}

$\mathrm{H}_{1}$ : Harga Minyak Dunia, Suku Bunga, Inflasi dan Nilai Tukar berpengaruh terhadap harga saham sektor pertambangan pada indeks LQ45 periode 2011-2018 secara parsial.

$\mathrm{H}_{2}$ : Suku bunga, harga minyak dunia, inflasi, nilai tukar (kurs) rupiah terhadap dollar Amerika berpengaruh terhadap harga saham sektor pertambangan pada indeks LQ45 periode 2011-2018 secara simultan.

\section{METODE PENELITIAN}

Metode penelitian yang digunakan dalam penelitian ini adalah metode deskriptif verifikatif. Penelitian ini menggunakan jenis data panel, dimana menggabungkan data cross 
section dan data time series. Jenis data yang digunakan dalam penelitian ini berupa data kuantitatif, dimana data tersebut berupa angka-angka historis dari data harga minyak dunia, suku bunga, inflasi, nilai tukar rupiah terhadap dollar Amerika dan harga saham. Data harga minyak dunia dalam penelitian ini diperoleh dari www.eia.gov, data suku bunga diperoleh dari www.bps.go.id dan www.bi.go.id, sedangkan data inflasi diperoleh dari www.bps.go.id, data nilai tukar (kurs) rupiah terhadap dollar Amerika diperoleh dari www.bi.go.id dan www.kemendag.go.id, dan data mengenai harga saham perusahaan sektor pertambangan berasal dari Bursa Efek Indonesia, investing.com dan https://finance.yahoo.com serta data mengenai emiten pertambangan mana saja yang masuk ke dalam list LQ45 berasal dari website Bursa Efek Indonesia (BEI). Teknik pengambilan sampel pada penelitian ini ialah Sampling Purposive, diperoleh 13 sampel perusahaan yang nantinya akan diuji.

Metode analisis data yang digunakan adalah regresi data panel, dimana akan dilakukan estimasi data panel yang terdiri dari 3 model regresi yaitu Common Effect, Fixed Effect dan Random Effect dengan sebelumnya diuji terlebih dahulu dengan 3 uji model regresi yaitu Uji chow, uji Hausman dan Uji Lagrange Multiplier. Lalu dilakukan Uji Asumsi klasik untuk mengetahui ada tidaknya pelanggaran asumsi-asumsi klasik. Pengujian asumsi klasik meliputi uji normalitas, uji multikolinearitas, dan uji heteroskedastisitas. Pengujian hipotesis dalam penelitian ini menggunakan beberapa teknik analisis, yaitu uji t dan uji F. Untuk mengetahui seberapa besar variabel $\mathrm{X}$ menjelaskan perubahan atau pergerakan variabel $\mathrm{Y}$ maka dilakukan uji koefisien determinasi $\left(\mathrm{R}^{2}\right)$.

\section{HASIL DAN PEMBAHASAN}

\section{Analisis Deskriptif}

Harga acuan minyak dunia dalam penelitian ini yaitu WTI (West Texas Intermediate). Harga minyak dunia dengan angka tertinggi terjadi pada tahun 2013. Angka harga minyak dunia dengan harga terendah yaitu pada tahun 2016. Tingkat suku bunga dalam penelitian ini yaitu tingkat suku bunga Bank Indonesia atau BI Rate. Tingkat suku bunga tertinggi terjadi pada tahun 2014. Suku Bunga acuan dengan angka terendah terjadi pada tahun 2017. Inflasi menyentuh angka tertinggi pada tahun 2013. Dan angka inflasi terendah terjadi pada tahun 2016. Nilai tukar tertinggi yaitu pada tahun 2018 dan nilai tukar dengan angka terendah terjadi pada tahun 2011.

\section{Uji Statistik}

\section{Pemilihan Model Terbaik}

Pemilihan Model menggunakan Uji Lagrange Multiplier (LM) Nilai probabilitas Breusch-Pagan (BP) sebesar $0.0000<0.05$ maka model yang cocok dalam penelitian ini adalah Random Effect Model.

\section{Uji Asumsi Klasik}

Nilai Prob. JB hitung sebesar $3.05>0.05$ dengan Probability sebesar $0.22>0.05$ sehingga dapat disimpulkan bahwa residual terdistribusi normal yang artinya asumsi klasik kenormalan telah terpenuhi.Tampilan matrik korelasi pair-wise correlation antar variabel independen menghasilkan nilai dibawah 0.80. Dapat disimpulkan bahwa tidak terdapat multikolinieritas.Model regresi dalam penelitian ini tidak terjadi heteroskedastisitas. Hal tersebut dapat dilihat dari nilai probabilitas harga minyak dunia, suku bunga, inflasi dan nilai tukar yang lebih besar dari 0.05. Harga minyak dunia sebesar 0.4031, suku bunga sebesar 0.7029 , inflasi sebesar 0.4599 dan nilai tukar sebesar $0.4206>0.05$. Dilihat dari tabel, nilai DW 0.886751. Dengan keterangan :dL $<\mathbf{d W}<\mathbf{d U}$. Maka tidak ada autokorelasi positif. 


\section{Pengujian Hipotesis \\ Pengujian Hipotesis (Uji-t)}

\begin{tabular}{lllll} 
Variable & Coefficient & Std. Error & t-Statistic & Prob. \\
\hline \hline C & 6.339834 & 7.585648 & 0.835767 & 0.4053 \\
Harga Minyak Dunia & 1.238466 & 0.468222 & 2.645041 & $\mathbf{0 . 0 0 9 5}$ \\
Suku Bunga & -1.905129 & 0.405256 & -4.701051 & $\mathbf{0 . 0 0 0 0}$ \\
Inflasi & -0.033285 & 0.279929 & -0.118906 & $\mathbf{0 . 9 0 5 6}$ \\
Nilai Tukar & -0.128427 & 0.669195 & -0.191912 & $\mathbf{0 . 8 4 8 2}$ \\
\hline \hline
\end{tabular}

Sumber : Data diolah (2019)

Hasil uji t menunjukkan harga minyak dunia dan suku bunga berpengaruh karena Prob. < 0.05

\section{Pengujian Hipotesis (Uji-F)}

$\begin{array}{llll}\text { F-statistic } & \mathbf{1 0 . 8 0 0 5 2} & \text { Durbin-Watson stat } & 0.886751 \\ \text { Prob(F-statistic) } & \mathbf{0 . 0 0 0 0 0 0} & & \end{array}$

Sumber : Data diolah (2019)

Oleh karena F-hitung lebih besar dari nilai F-tabel yaitu $10.80>3.84$ dan nilai probabilitas lebih kecil dari nilai alpha (0.05) yaitu $0.000000<0.05$. Hal ini berarti bahwa variabel independen secara simultan berpengaruh terhadap variabel dependen.

\section{Koefisien Determinasi}

Nilai R-squared sebesar 0.303808 atau 30\%. Koefisien determinasi $\left(\mathrm{R}^{2}\right)$ menunjukkan bahwa kemampuan variabel harga minyak dunia, suku bunga, inflasi dan nilai tukar dalam menjelaskan varians dari variabel harga saham adalah sebesar 30\%. Sedangkan $70 \%$ varians variabel harga saham dijelaskan oleh variabel lain diluar penelitian, seperti misalnya suku bunga The Fed, neraca perdagangan, pertumbuhan ekonomi dan tingkat pengangguran. Maka kemampuan variabel harga minyak dunia, suku bunga, inflasi dan nilai tukar dalam menjelaskan variabel harga saham amat terbatas.

\section{Pembahasan Hasil Penelitian}

Dari hasil perhitungan secara uji parsial koefisien regresi harga minyak dunia bertanda positif sebesar 1.238466 dengan nilai t-hitung untuk variabel adalah 2.645041 dengan tingkat signifikansi sebesar 0.0095 dilihat dari t-hitung yang lebih besar dari t-tabel yaitu $2.645041>2.30600$ dengan tingkat signifikansi sebesar 0.0095 yang lebih kecil dari 0.05 , dengan kata lain harga minyak dunia berpengaruh signifikan terhadap harga saham sektor pertambangan pada Indeks LQ45 periode 2011-2018. Berarti hipotesis pertama dapat diterima. Hal ini terjadi karena emiten-emiten tambang di Indonesia melakukan kegiatan dimana menggunakan sumber energi minyak dunia, maka ketika harga minyak dunia naik dimana permintaan minyak dunia naik sedangkan persediaan terbatas akan menaikkan harga minyak dunia yang akan mempengaruhi pergerakan harga saham pertambangan pada Indeks LQ45.

Dari hasil perhitungan secara uji parsial koefisien regresi harga minyak dunia bertanda negatif sebesar -1.905129 dengan nilai t-hitung untuk variabel adalah -4.701051 dengan tingkat signifikansi sebesar 0.0000 dilihat dari t-hitung yang lebih kecil dari t-tabel yaitu $-4.701051<2.30600$ dengan tingkat signifikansi sebesar 0.0000 yang lebih kecil dari 0.05, dengan kata lain suku bunga berpengaruh signifikan kearah negatif terhadap harga 
saham sektor pertambangan pada Indeks LQ45 periode 2011-2018. Berarti hipotesis pertama dapat diterima. Hal ini terjadi karena perusahaan-perusahaan tambang pada Indeks LQ45 melakukan pinjaman pada bank, sehingga akan mempengaruhi pergerakan harga saham.

Dari hasil perhitungan secara uji parsial koefisien regresi inflasi bertanda negatif sebesar -0.033285 dengan nilai t-hitung untuk variabel adalah -0.118906 dengan tingkat signifikansi sebesar 0.9056 dilihat dari t-hitung yang lebih kecil dari t-tabel yaitu -0.118906 $<2.30600$ dengan tingkat signifikansi sebesar 0.9056 yang lebih besar dari 0.05, dengan kata lain inflasi tidak berpengaruh terhadap harga saham sektor pertambangan pada Indeks LQ45 periode 2011-2018. Maka hipotesis pertama tidak dapat diterima. Hasil penelitian ini mendukung penelitian yang dilakukan Dwiana, dkk (2018) dimana inflasi tidak mempengaruhi variabel harga saham pada Indeks Kompas 100 secara parsial. Hal tersebut diatas terjadi karena saat inflasi maka kebijakan moneter terkait yaitu suku bunga akan dikeluarkan untuk menekan inflasi. Karena pada poin b dikatakan bahwa suku bunga mempengaruhi harga saham maka pada poin ini inflasi tidak akan berpengaruh karena ketika ada inflasi maka suku bunga akan dinaikkan.

Dari hasil perhitungan secara uji parsial koefisien regresi nilai tukar bertanda negatif sebesar -0.128427 dengan nilai t-hitung untuk variabel adalah -0.191912 dengan tingkat signifikansi sebesar 0.8482 dilihat dari t-hitung yang lebih kecil dari t-tabel yaitu -0.191912 $<2.30600$ dengan tingkat signifikansi sebesar 0.8482 yang lebih besar dari 0.05, dengan kata lain nilai tukar tidak berpengaruh signifikan terhadap harga saham sektor pertambangan pada Indeks LQ45 periode 2011-2018. Maka hipotesis pertama tidak dapat diterima. Hasil penelitian ini mendukung penelitian yang dilakukan Dwiana, dkk (2018) dimana nilai tukar tidak mempengaruhi variabel harga saham pada Indeks Kompas 100 secara parsial. Hal ini terjadi karena pada dasarnya perusahaan-perusahaan pertambangan melakukan kegiatan ekspor dimana mata uang yang akan sangat diperhatikan ialah US Dollar. Karena nilai tukar disini ialah nilai tukar rupiah terhadap US Dollar maka rupiah tidak akan terlalu mempengaruhi harga saham emiten tambang pada Indeks LQ45.

Dari hasil uji f, diketahui nilai F sebesar 10.80052 dengan probabilitas 0.000000 . karena probabilitas lebih kecil dari nilai alpha (0.05) dan F-hitung lebih besar dari F-tabel yaitu 10.80052 > 3.84 dapat dikatakan bahwa harga minyak dunia, suku bunga, inflasi dan nilai tukar secara bersama-sama berpengaruh terhadap harga saham. Maka hipotesis kedua terbukti atau dengan kata lain secara simultan harga minyak dunia, suku bunga, inflasi dan nilai tukar berpengaruh terhadap harga saham sektor pertambangan pada indeks LQ45 periode 2011-2018.

\section{SIMPULAN}

Secara parsial harga minyak dunia dalam penelitian ini yaitu WTI (West Texas Intermediate) dan suku bunga berpengaruh terhadap harga saham perusahaan pertambangan yang masuk ke dalam Indeks LQ45 pada periode 2011 hingga 2018.Secara parsial inflasi dan nilai tukar tidak berpengaruh terhadap harga saham perusahaan pertambangan yang masuk ke dalam Indeks LQ45 pada periode 2011 hingga 2018.Berdasarkan hasil uji hipotesis secara simultan, harga minyak dunia, suku bunga, inflasi dan nilai tukar berpengaruh terhadap harga saham perusahaan pertambangan yang masuk ke dalam Indeks LQ45 pada periode 2011 hingga 2018.

\section{DAFTAR PUSTAKA}

\section{Buku dan Skripsi}

Ekananda, Mahyus. 2014. Ekonomi Internasional. Jakarta: Erlangga.

Ihsan Firmansyah. 2018. Analisis Perbandingan Return Dan Risk Antara Saham 
Syariah Dan Saham Konvensional (Studi Pada Saham Syariah yang Terdaftar Di Jakarta Islamic Index (JII) Dan Saham Konvensional Berdasarkan Jakarta Compostie Index (JCI) Periode 2013-2017). Bandung : Repository Widyatama.

Inas. 2016. Analisis Pengaruh Harga Emas Dunia, Harga Minyak Dunia, Jumlah Uang Beredar, Inflasi, Kurs Rupiah Terhadap Jakarta Islamic Index (JII) Periode 2011-2015. Jakarta : Universitas Islam Negeri Syarif Hidayatullah.

Indah Fitriani. 2018. Mekanisme Kinerja Keuangan Dan Pengaruhnya Terhadap Harga Saham (Studi pada Perusahaan Sektor Pertambangan yang Terdaftar di Bursa Efek Indonesia Periode 2011-2016). Bandung : Repository Widyatama.

Natsir, M. 2014. Ekonomi Moneter dan Perbankan Sentral. Jakarta: Mitra Wacana Media.

Restia Fauziana. 2018. Pengaruh Mekanisme Corporate Governance, Struktur Modal, Volume Transaksi Saham, Dan Biaya Keagenan Terhadap Harga Saham (Studi Kasus Pada Saham Indeks Kompas 100 Yang Terdaftar Di Bursa Efek Indonesia Periode 2012-2016). Bandung : Repository Widyatama

Sapitri Wulandari. 2018. Pengaruh Inflasi, Nilai Tukar dan Suku Bunga Terhadap Kinerja Harga Saham (Studi Kasus pada Sub-sektor Perbankan yang Terdaftar di Bursa Efek Indonesia Periode 2008-2017). Bandung : Universitas Sangga Buana YPKP Tidak dipublikasikan.

Sugiyono. 2018. Metode Penelitian Kuantitatif, Kualitatif, dan R\&D. Bandung : Alfabeta.

\section{Sumber Jurnal}

Darmawan, Anisa. 2018. Pengaruh Ekonomi Makro dan Harga Komoditas Tambang Dunia Terhadap Indeks Harga Saham Sektor Pertambangan di Indonesia. Malang : Universitas Brawijaya.

Lestari, dkk. 2018. Pengaruh Suku Bunga, Kurs, Tingkat Inflasi, Harga Minyak Dunia, Dan Harga Emas Dunia Terhadap Harga Saham Pada Indeks Kompas 100. Universitas Lancang Kuning

Sulasmiyati, Noel dkk. 2016. Pengaruh Harga Minyak Mentah Dunia, Inflasi, Suku Bunga (Central Bank Rate), dan Nilai Tukar (Kurs) Terhadap Indeks Harga Saham Sektor Pertambangan di ASEAN (Studi pada Indonesia, Singapura, dan Thailand Periode Juli 2013-Desember 2015). Malang : Universitas Brawijaya.

Sumartio, Agustina. 2014, Analisa Faktor-faktor yang Mempengaruhi Pergerakan Harga Saham pada Perusahaan Pertambangan. Medan : STIE Mikroskil.

Suwandy. 2014. Analisis Pengaruh Inflasi, Nilai Tukar, Bi Rate, Harga Minyak Dunia, Harga Emas Dunia, Dan Indeks Straits Times Terhadap Return Indeks LQ 45 Pada Bursa Efek Indonesia Tahun 2003-2013. Universitas Dipenogoro.

Tamayo, Adrian. 2015. Simulating the Effects of Macroeconomic Activities on the 
Sectoral Indices of Philippine Stocks Exchange. Proceedings of Business and Social Sciences Research Conference 10 - 11 December 2015, Ambassador Hotel, Bangkok, Thailand.

Topowijono, Suhadak, dkk. 2014. Pengaruh Kurs Rupiah, Inflasi Dan Bi Rate Harga Saham (Studi Pada Indeks Sektoral Bursa Efek Indonesia Periode 20052013). Universitas Brawijaya.

\author{
Sumber Internet \\ amazin.com \\ www.eia.gov \\ www.bps.go.id \\ www.bi.go.id \\ www.kemendag.go.id \\ https://finance.yahoo.com \\ https://www.idx.co.id \\ www.cnbcindonesia.com \\ https://investasi.kontan.co.id
}

